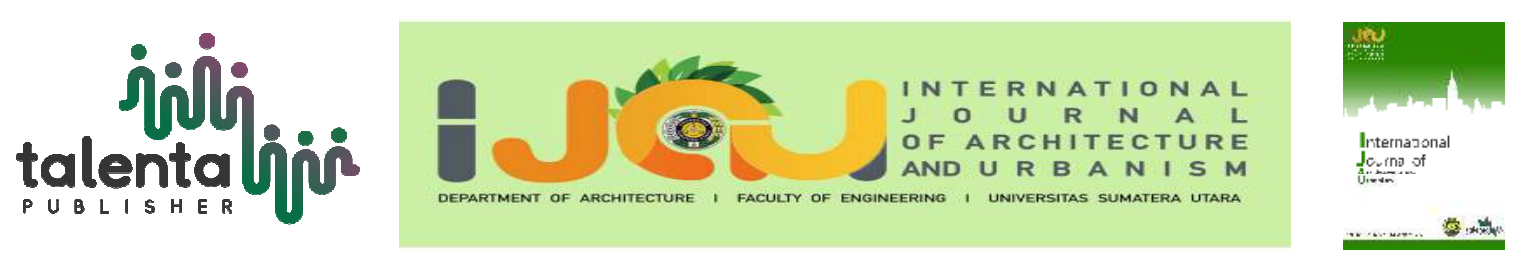

\title{
Local Wisdom in Coffee House Design to Promote Gayo Culture and Tourism
}

\author{
Sylviana Mirahayu Ifani ${ }^{1^{*}}$ \\ ${ }^{I}$ Universitas Pembangunan Panca Budi, Medan, Indonesia
}

\begin{abstract}
Despite being the fourth largest coffee producing country, Indonesia has low domestic coffee consumption. Recent growing trend of coffee house may help increase the consumption. Gayo Highlands as the origin of a specialty grade coffee may also be benefitted from the growing trend. Coffee house culture in Gayo has also been growing recently. Coffee as the main commodity in Gayo Highlands has influenced the Gayo culture. Coffee culture can help preserve and promote Gayo culture. This paper explains how philosophical design of traditional Gayo architecture as Gayo local wisdom can be adopted into coffee house design in Gayo Highlands. It discusses some elements of traditional Gayo house which can be adopted to the design of Gayonese coffee house. This article shows that the implementation of traditional Gayo house elements such as pëpantarën, kërawang and këlélékën can help preserve Gayo culture and promote cultural tourism.
\end{abstract}

Keyword: architecture, coffee house, gayo lut

\section{Introduction}

Coffee has become one of the most important commodities in Indonesia. It ranked fifth in terms of export value of estate crop commodities [1]. Despite being the fourth largest coffee producing country, Indonesia's coffee consumption per capita is still low [2]. Out of five biggest producing countries, e.g. Brazil, Vietnam, Colombia, Indonesia, and Ethiopia, only Brazil and Colombia listed among the top fifty of coffee consumption per capita, both ranked tenth and $44^{\text {th }}$ respectively. Finland, Norway, and the Netherlands are the top three of coffee consumption per capita [3]. Government has set a target to increase domestic consumption. The growing trend of coffee house lately may help increase the consumption.

One of the biggest coffee producing provinces in Indonesia is Aceh. It is the fourth largest coffee producing province in Indonesia, behind Sumatera Selatan, Lampung, and Sumatera Utara provinces. It produced $7.83 \%$ of the country's 632,460 tons of coffee production in 2015 [1]. Around $91.50 \%$ of the province's coffee production is produced in the Gayo Highlands

\footnotetext{
*Corresponding author at: Universitas Pembangunan Panca Budi, Medan, Indonesia

E-mail address: s.hayuifani@gmail.com
} 
area which comprises Aceh Tengah (the Gayo Lut regions), Bener Meriah, and Gayo Lues regencies. Gayo is a tribe in the highland region of Aceh Province which reside in the side of Bukit Barisan mountain range and a lake called Lut Tawar. As a mountainous area with altitude of 600-1,800 meters above sea level, Gayo Highlands has been well-known worldwide for its high quality coffee. However, less is known about Gayo culture and its abundant tourism potential.

Propelled mainly by coffee commodity, Takéngën as the main city for Gayo people has experienced rapid change in the past fifty or so years which affects its architectural face. In contrast with traditional Gayo houses which spirit was centered on paddy farming, rituals, gender boundaries, and local wooden materials, the contemporary Gayo houses have developed based on practical activity as it is changed to coffee farming, gender generalization, and modern materials. Nevertheless, coffee culture in Gayo is not as well-known as their coffee itself. Only recently coffee houses have become a growing trend like in many other regions in Indonesia. Quality coffee has been one of the biggest attractions for tourists to come to the region. Coffee house can play a role in preserving culture and promoting tourism in Gayo. Coffee house as part of coffee culture can be an attraction for tourists to come to Gayo. As coffee smallholders are usually not gaining much from the commodity, the development of coffee-related tourism in Gayo may improve their livelihood. This paper aims to show how coffee as an important commodity in Gayo Highlands can help preserve Gayo culture and promote cultural tourism in the Highlands by implementing local wisdom in coffee house design. It shows that there are some elements of traditional Gayo architecture especially Gayo house that can be implemented in the design of Gayo coffee house.

\section{Traditional Architecture Gayo Lut Loacal Wisdom}

Traditional Gayo Lut architecture is divided into three building types based on its function. Those are places of worship, buildings for storage, and dwelling houses. Common kampöng (village) in the Highlands have at least one from each of those three building types to support them in carrying out day-to-day tradition.

\subsection{The Place of Worship}

The place of worship is a place for conducting congregational prayers and reciting holy Qur'ān in accordance with Islamic guidance. It appears in the form of buildings, such as mësëgit (masjid), mërsah (mësëgit in a simpler form specifically for men), and döyah (mërsah's counterpart which is reserved for women) as shown in Figure 1 [4]. Mërsah used to serve as a 'second home' for traditional Gayo men. Boys over the age of 8 years, men who are not yet married, widower or traveler commonly spent more time to pray, socialize, and even stayed at 
mërsah. According to the Gayo ëdët (local custom), it is këmél (such an embarrassment) for men to spend more time at their houses than at the mërsah (Figure 1).

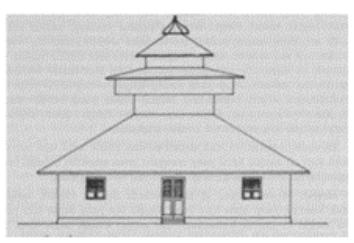

(a) Mësëgit

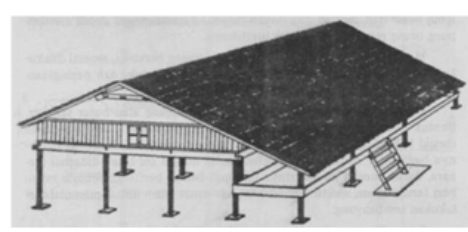

(b) Mërsah

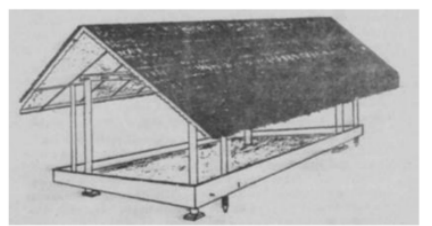

(c) Döyah

Figure 1. Sketches of Gayo Lut Traditional Worship Buildings

\subsection{Storage Buildings}

Storage buildings were another important architectural object owned by each household inside a kampöng (village). They were a manifestation of the Gayo livelihoods because they had a primary function of storing paddy grain. There were three types of traditional storage buildings according to its size, called bëranang, manah and këben as shown in Figure. 2 [4]. The size of a storage to be built depended on the amount of rice its owner could produce. Since the storage buildings were standalone buildings outside the house, obviously it became a visible indicator of a household prosperity seen by general public (Figure 2).

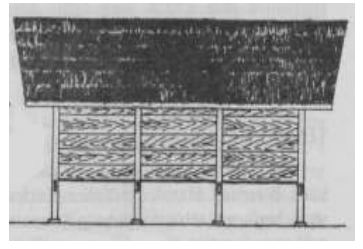

(a) Bëranang

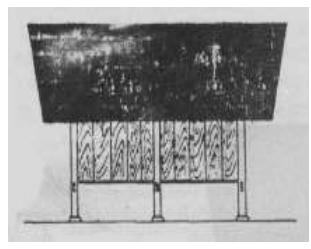

(b) Manah

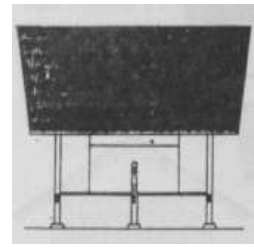

(c) Këben

Figure 2. Sketches of Gayo Lut Traditional storage buildings

\subsection{Dwellings}

Dwelling houses in local term is called umah. The Gayo Lut traditional house was a longhouse that served as home to several families belonged to the same paternal lineage living under one roof. Currently, there is only one authentic traditional house of Gayo Lut survives. It is estimated that the house which located in kampöng Toweren was built before 1930s. The facade and house plan reportedly still retain its original form even though the condition of the house is increasingly deteriorating with age as shown in Figure 3. 


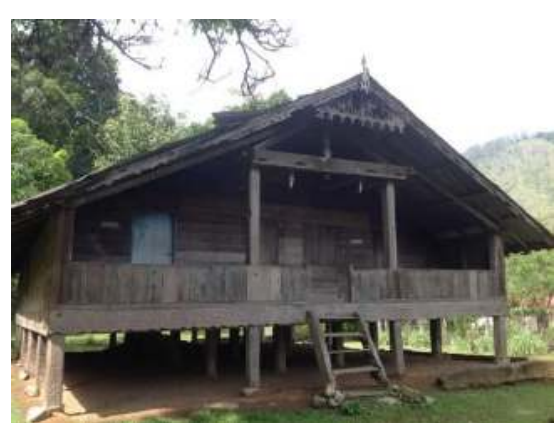

Figure 3. Traditional Gayo Lut house in kampöng Toweren in 2015

The Gayo Lut traditional house is an elevated-typed of house with the floor (tele) raised on posts 2 to 2.5 meters above the ground. According to Hurgronje [5] and Kreemer [6], raising the floor so as to create a section under the house (këlétén) was an act of imitation by the Gayo from traditional Aceh house. Research reports and cultural inventory project of the province of Aceh explain that the raising of the floor above ground level was done with the intention to avoid wild animal attacks such as tigers, snakes, and centipedes, as well as to facilitate bathing elderly and also those who passed away [4]. There is no evidence found with regard of the association between the chosen vertical section designs of the house with mystical or spiritual meanings.

The wooden posts (suyön) which supported the house were made of pine wood (uyëm) or other types of local woods. Under a normal circumstance, lengthwise the house was oriented eastwest in which the staircase located on the east or north side of the house. The orientation was chosen due to the Highlands climate where wind strongly blew from the northwest, so it was expected to be able to avoid it from damaging the roof [4]. Short sides of the house consisted of 3-4 posts that generated 2-3 room partitions. While the long sides consisted of 6-9 posts that generated 5-8 room partitions. The distance between two posts is about 3 meters. The illustration of the house exterior can be seen in Figure 4.

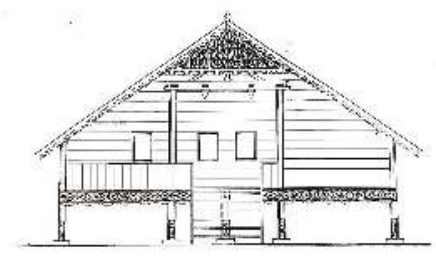

(a) Front view

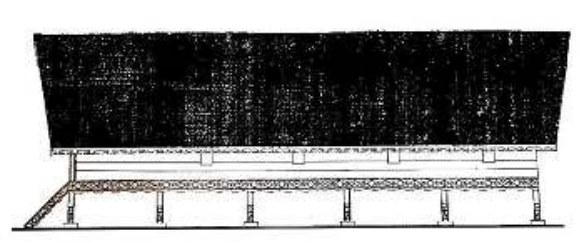

(b) Side view

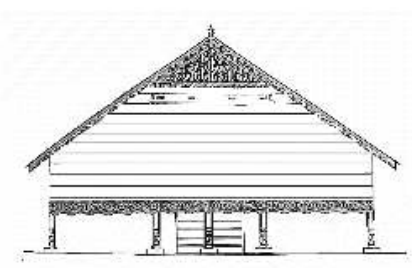

(c) Rear view

Figure 4. Gayo Lut Traditional house

The spaces of traditional Gayo Lut house consisted of stairs in front of the house which usually had an odd step numbers. Climbing up through the stairs, one would find an entry leading to lëpo. Lëpo was a transitional terrace towards the house interior and also used as a sitting room 
when family members wanted to sunbathe or weave mats. Lëpo had a direct access that was commonly not separated by wall to the room on the left side of the house called sërambi rawan (men gallery). On the opposite, lëpo was separated by a wall in the right side of the house with anyōng and also sërambi banan (women gallery). The wall had a door that was closed at night called pintu kaol (the great door). The space elements of traditional Gayo Lut house are illustrated as in Figure 5.

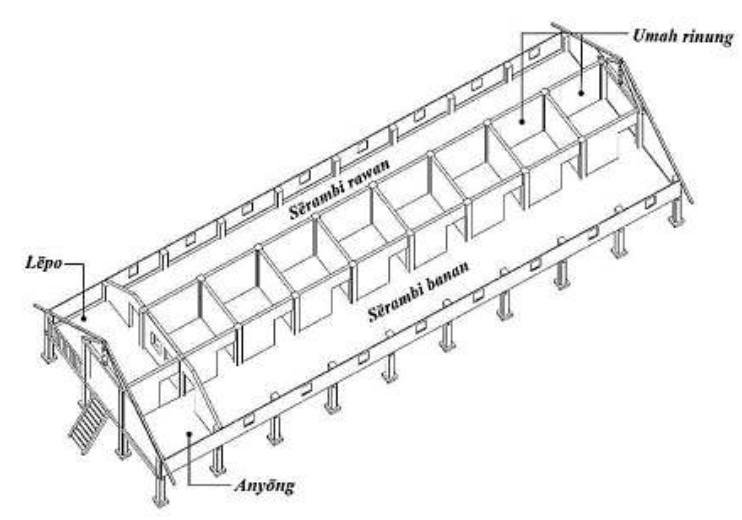

Figure 5. Room arrangement in Gayo Lut traditional house

Decorative elements of traditional Gayo Lut houses were woodcarvings inspired by natural phenomenon, floral and animals. Gayo art is famous for its spiral-shaped carving, e.g. the kërawang. The carving of traditional Gayo Lut house was made using simple equipment such as cëkéh (a tool used for woodcarving). The carving then left with its natural color without being painted. For carving motifs which were inspired by natural phenomenon, Gayo people were influenced by the things they saw in their daily life. Ëmun bërangkat (drifting clouds), for example, is a manifestation of natural situation of Takéngën in certain seasons that have a view of the clouds drifting over the lake from east to west. Animal motifs came in the form of bawal danau (one of fishes that are commonly found in the Lake Lut Tawar), chicken and dragon. The carving on the traditional Gayo house in kampöng Toweren show that the motif like ulën-ulën (the Moon) is not found in the lower part of the building, while ëmun bërangkat is also not found in the lower part of the building except on the staircase and doors. Animal motifs are not found on the top and bottom of the house, but they are found in the middle of the house. Meanwhile, floral motifs can be found in all parts of the house either top, middle or bottom (Figure 6). 


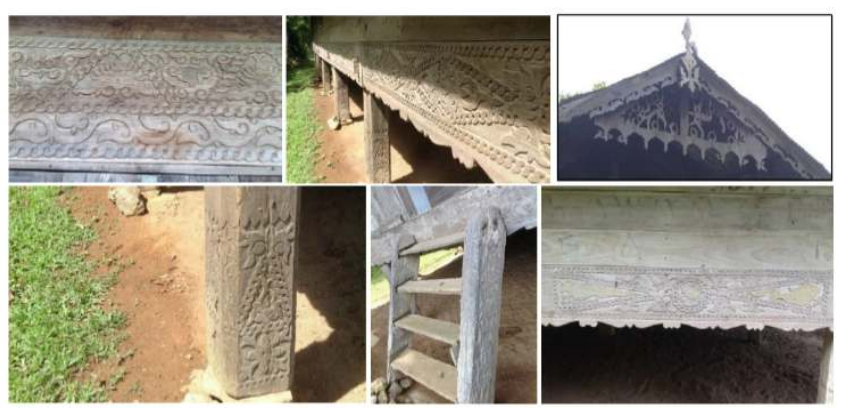

Figure 6. Decorative elements on traditional Gayo Lut house

\section{Coffee Culture}

European Association for Tourism and Leisure Education define cultural tourism as "the movement of persons to cultural attractions away from their normal place of residence, with the intention to gather new information and experiences to satisfy their cultural needs". Coffee can be an attraction of cultural tourism, since coffee as part of food and beverage tourism is a cultural experience [7]. Coffee is experienced through travel and besides collecting coffee experiences, travelers may collect objects related to coffee as souvenirs or may purchase coffee beans as a souvenir.

The spreading of coffee initiated the emergence of coffee culture in many parts of the world. As one of the most important beverage commodities, many cultures have been evolved surrounding coffee. As the drinking of coffee became popular, countries formed their own rituals around coffee, each region's coffee taste acknowledged as being related to its history, work habits and style [8]. Around the world, coffee houses have evolved as social meeting places, or third place for meeting away from home and work [7]. Coffee is associated with various forms of food service outlets, such as coffee houses, coffee shops, coffee bars and cafés. Each types of these establishments has different levels of informality in settings where coffee and food are served [7]. While coffee houses share common aspects, i.e. coffee and sociality, they vary in the customers they attract through unique atmospheres, a variety of services and ancillary products (books, music, art work), and different qualities, origins, blends, or preparations of coffee [9].

Davids argued that coffee houses are seen as a place to relax, discuss, socialize and study [10]. In Vienna, coffee house culture is acknowledged as having played a critical part in a vibrant intellectual and artistic activity at the beginning of the $20^{\text {th }}$ century. In Paris, such coffee house culture is acknowledged to have contributed to modernity [11].

Coffee culture has been better recorded in consuming countries than producing countries. Even now, the consumption of coffee in Indonesia is much less compared to that in consuming countries such as the United States. Coffee house has been evolved as an institution in Gayo Highlands and many other places in Indonesia. The words have been associated with chatting 
between visitors, from local issues to the politics of the country. "Obrolan warung kopi" (coffee house chat) has been a common culture in many regions in Indonesia even since 1970's when a popular comedy group Warkop DKI was named after it. Recently coffee drinking has become more popular, perhaps due to the promotion of coffee drinking and socializing through media such as movies and travel documentaries.

\section{Coffee in Gayo Highlands}

Coffee is one of the world's important beverage commodities. Along with cocoa and tea, it is included in World Bank's beverage price index. According to Tannahill, as cited by Jolliffe, cultivation of the wild Arabica coffee (Coffea arabica) may have begun in the sixth century, although the first written reference is attributed to a tenth-century Arab physician [12]. Originated from Ethiopia, there is the common assumption that European merchants and bureaucrats were the engine that powered the growth of the world coffee economy. However, the assumption may have neglected the role of Muslims in spreading the crop. It is said that by 1438 or so Sufis in Yemen were using a newly discovered stimulant to keep awake and alert during their religious exercises and devotions. Coffee and the first coffee houses worried Islamic rulers, jurists, and market inspectors from the outset. In 1511 in Mecca, Islamic jurists decreed that although some places that served the beverage might pose a threat to public morality, the drink itself could not be outlawed simply on the supposition of its evil effects without just proof. This principle became part of Islamic law and ensured that coffee houses, although often shut, were never banned — as was the sale and consumption of alcohol.

Wherever coffee and coffee houses spread in the Muslim world, whether to Cairo or Istanbul by 1600 or so, similar fears arose alongside the use of the beverage by Sufis and writers. The first book to document the effects of caffeine was Abdalcader Alanzar's treatise (1587) concerning coffee that it is lawful for a Moslem to drink it. This Muslim writer discussed the origins, effects, diffusion, and disputes at Mecca over cahouah (coffee). This is one of the first publications reflecting the intellectual life of coffee and coffee house [13].

Ottoman Turks brought coffee to Constantinople in the mid fifteenth century and the first coffee house, Kiva Han, was opened in 1457. However, it was not until the 17th and 18th centuries that coffee moved from a novel to a popular drink [14]. In both London and Paris, coffee houses became centers for coffee consumption and discussion [15]. Civitello argued that the emergence of these coffee houses as public meeting places has change social and political habits [16].

Arabica beans were planted in India by Muslim pilgrims in the seventeenth century, long before the British took any interest in the crop. Dutch imports of seedlings into Java in the 1690s have been said as the "origins" of coffee cultivation in monsoon Asia, but the seedlings came from India via Muslim traders. Moreover, Dutch efforts at growing coffee in Indonesia may well have 
been preceded by those of Muslim travelers, especially in Sumatra. An Islamic expertise in early coffee cultivation ran parallel to that of Europeans [17]. Since the pilgrimage to Mecca was also an opportunity for trading commodities, coffee might have been traded in the Holy City and brought to Indonesia by pilgrims. Gayo people have been exposed to Islam as early as $1000 \mathrm{BC}$ when Linge kingdom was founded, even though some argue that the Gayo converted to Islam under Sultan Iskandar Muda (r. 1607-36) of Pasai kingdom [18]. Thus, it is possible that coffee was introduced to Gayo long before the Dutch grew it as an export commodity.

During the 1930s, the Dutch established tea and coffee estates north of the main town of Takéngën in an effort to transform the Gayo Highlands into an agricultural export center. After 1945, farmers began to carve the estates into smallholder coffee farms, and their numbers have risen steadily ever since. The attractiveness of coffee growing increased throughout the $1960 \mathrm{~s}$, and particularly by the late 1970s, as the local producer price for one kilogram of unroasted coffee beans rose from about Rp. 300 in the mid-1970s to Rp. 2000 by the end of the decade. Farmers moved into the uncultivated forest areas to the north and west of Takéngën to open coffee farms, and expanded the number of hectares harvested from 17,000 in 1971 to 31,000 in 1984 [19]. Nowadays, Gayo Highlands produce around 91.50\% of the Aceh province's coffee production [1]. Coffee farming has dominantly become part of contemporary Gayonese livelihood.

\section{Implemening Local Wisdom in Gayonese Coffee House Design}

There are basically two types of coffee houses which are common in Gayo, e.g. keude kupi (coffee shop) and café. Although most coffee produced in the Highlands is Arabica (Coffea arabica), local people usually drink Robusta coffee (Coffea canephora). The design of a coffee house may determine cultural and tourism influences of the coffee house. Gayonese traditional architecture can be implemented in the design of Gayo coffee houses. Even though as described before that traditional Gayonese architecture were centered on traditional commodity, which was paddy, the shifting of main local commodity to coffee does not mean the Gayonese should lost value of their traditional architecture. Designing coffeeehouses based on traditional architecture will help preserve and promote Gayo decent culture.

Gayo coffee houses may combine traditional and contemporary architecture styles in their design. A traditional Gayo house might consist of four to nine private rooms called umah rinung depending on the number of families occupying the house. Umah rinung were located in the central part of the house and served as a bedroom for a couple. Each room had a fireplace (dapōr këlélékën) which was fueled by firewood or pine seed (galih) and used for keeping the body warm (bëdiang, muniru). As common weather in Gayo Highlands is relatively cool (in certain season could reach 14 Celsius degrees), coffee houses can use fireplace to make 
costumers feel warm and comfortable during cold days as how traditional people used dapōr këlélékën inside the house.

Traditional Gayo houses had male- and female-only spaces, separated from common area. Sërambi rawan (men gallery) was a long single room used mainly for male activity and receiving male guests. Sërambi banan (women gallery) was a place devoted to the activities of female family members such as cooking, weaving and also welcoming female guests. Gayo coffee houses can implement this feature by creating male- and female-only spaces in addition to the common area which is accessible for both gender. Such design will represent Gayo ëdët of sumang (appropriateness) and këmél. Sumang appeared in the form of traditional rule on how to interact between men and women.

In terms of building types, traditional Gayo house was an elevated house in which the phrase "entah ku atas" which means "please come upstairs" was commonly used to invite someone into the house (by going up to the elevated floor) as a form of hospitality [19]. Currently, when the type of house has been turned into a ground-level single house, the same phrase is still often used to invite someone up onto pëpantarën. Pëpantarën is a kind of raised surface for seating and is generally found in the family room or kitchen. In this case, it can be said that the existence of pëpantarën is a transformation of an elevated traditional Gayo house and a symbol of hospitality as well as to accommodate social activity. Gayo coffee houses can use pëpantarën as part of their seating area instead of using general chair and coffee table as in the western tradition.

In the contemporary Gayo society, male family members are no longer making mërsah as their second home [20]. This situation, and the findings that one of the best moments for family communication happens when the family has finished praying together at home, has led to the emergence of the need for a special room for worship in the house to accommodate both activities. As Gayo ëdët is strongly tied to Islamic law, it is also important for Gayo coffee houses to provide space to offer Salah (Islamic daily prayer).

Another element of traditional Gayo houses that can be used for the design of Gayo coffee houses is the application of decorative elements. Decorative elements of traditional Gayo houses were woodcarvings inspired by nature. Gayo art is famous for its spiral-shaped carving, i.e. the kërawang. The use of kërawang as contemporary building ornament in Takéngën is very rare except in government buildings.

\section{Acknowledgement}

Author would like to thank all people who have shared the information on Gayo culture and helped finish this article. 


\section{REFERENCES}

[1] M. o. A. R. o. Indonesia, Agricultural Statistics 2015, Center for Agricultural Data and Information System, Jakarta, 2015.

[2] H. D. o. t. G. C. Trade, "International Coffee Organization," 2016. [Online]. Available: http://www.ico.org/historical/1990\%20onwards/PDF/1b-domestic-consumption.pdf.

[3] C. Informer, "Caffeine (Coffee) Consumption by Country," 2013. [Online]. Available: http://www.caffeineinformer.com/caffeine-what-the-world-drinks.

[4] Z. A. Abdul Hadjad, Arsitektur Tradisional Provinsi Daerah Istimewa Aceh., Jakarta: History and Culture Research Center of the Ministry of Education and Culture, 1984.

[5] C. S. Hurgronje, Het Gajoland en zijne Bewoners, Batavia, 1903.

[6] P. J. Nas, Indonesian Houses: Survey of Vernacular Architecture in Western Indonesia., 1998.

[7] P. Boniface, Tasting Tourism: Travelling for Food and Drink, Ashgate: Aldershot, 2003.

[8] C. a. S. J. Calvert, Coffee, the Essential Guide to the Essential Bean, New York: Smallwood and Stewart Inc., 1994.

[9] C. M. Tucker, Coffee Culture: Local Experiences, Global Connections, New York: Routledge, 2011.

[10] K. Davids, Coffee: A Guide to Brewing and Enjoying Coffee, San Francisco: 101 Productions, 1979.

[11] J. Habermas, The Structural Transformation of Public Space: An Enquiry into a Category of Bourgeois Society, Oxford: Polity Press, 1989.

[12] L. Jolliffe, Common Grounds of Coffee and Tourism, Bristol: Channel View Publications, 2010.

[13] Ed. Leona Ritter, Ed. W. Scott Haine, Ed. Jeffrey H. Jackson, The Thinking Space: The Café as a Cultural Institution in Paris, Italy and Vienna., Surrey: Ashgate Publishing Limited, 2013.

[14] B. Cowan, Social Life of Coffee: The Emergence of the British Coffee House, New Haven: Yale University Press, 2005.

[15] J. S. D. a. S. K. Schapira, The Book of Coffee and Tea, New York: St. Martin's Press, 1975.

[16] L. Civitello, Cuisine and Culture: A History of Food and People, Hoboken: John Wiley \& Sons, Inc., 2005.

[17] William Gervase Clarence-Smith, Ed. Steven Topik, Introduction: Coffee and Global Development." The Global Coffee Economy in Africa, Asia, and Latin America 1500 1989, Cambridge: Cambridge University Press, 2000.

[18] A. H. Hill, Hikayat Raja-Raja Pasai., J of the Malayan Branch of the Royal Asiatic Society, 1960. 
[19] J. R. Bowen, Death and the History of Islam in Highlands Aceh, 1984.

[20] S. M. Ifani, The Study of Traditional House as Design Guidelines for Contemporary Houses in Takéngën, Indonesia, Vienna: Proceedings of 8th EuroSEAS Conference, 2015. 